\title{
Development and nutritional analysis of healthy chicken soup supplemented with vegetables in Viet Nam
}

\author{
1, ${ }^{*}$ Thuy, N.M., ${ }^{1}$ Hang, L.T., ${ }^{1}$ Triep, T.L., ${ }^{2}$ Tan, N.D. and ${ }^{1}$ Tai, N.V. \\ ${ }^{1}$ College of Agriculture, Can Tho University, Can Tho city, Viet Nam \\ ${ }^{2}$ Faculty of Agriculture and Natural Resources, An Giang University, Long Xuyen city, Viet Nam
}

\begin{abstract}
Article history:
Received: 9 July 2019

Received in revised form: 14 August 2019

Accepted: 17 August 2019

Available Online: 22 August 2019
\end{abstract}

Keywords:

Mixed-soup,

Chicken,

Dehydrated vegetables,

Nutritionally balanced diet

DOI:

https://doi.org/10.26656/fr.2017.4(1).248

\begin{abstract}
The present study was undertaken to formulate nutritious soup mix from chicken and locally available vegetables in Viet Nam. The drying was done by using a cabinet dryer (for vegetables) at a constant air flow rate and temperature or freeze-drier (for chicken) at varying times. The studies were carried out by mixing ingredients into 4 formulas. The chemical and physical characteristics of the product were analysed. The total energy, energy balance in terms of the major sources of energy, i.e. carbohydrate, protein and fat were calculated. In addition, the percentage of daily value (\% DV) was calculated and the Nutrition facts of soup were established. Among various recipes, the mixed soup containing $9.2 \%$ freeze-dried chicken, $23.7 \%$ full cream powder, $28.8 \%$ potato starch, $19.8 \%$ of vegetables powder (which include $3.2 \%$ pumpkin, $3.8 \%$ tomato, $3.8 \%$ carrot, $9 \%$ potato), $2.4 \%$ seaweed, $11.4 \%$ seasoning and $2.8 \%$ sugar was the best among the four mixtures evaluated. During the storage period of 5 months, the moisture content, water activity and color of the dried soup mixture have changed but not significantly. The total colony forming units of soup mix $(\mathrm{CFU} / \mathrm{g})$ was below the recommended level (Vietnamese Standard - QCVN 11-4:2012/BYT).
\end{abstract}

\section{Introduction}

The soup was found to be a very fast form of cookery. In this modern era, instant soup can become an alternative food for breakfast because of its high energy and nutrient content, ease of preparation and minimum serving time (Sunyoto et al., 2012). Soup can be made from chicken with various other ingredients. In Viet Nam, the price of industrial chicken breast is relatively low in comparison to other types of meat. It is considered as an available source of high-quality protein, a low portion of saturated fat and other nutrients that are necessary for body functioning. Therefore, chicken meat is recommended for consumption by all age groups. The chicken breast used in instant soup mixes often undergo freeze-drying that helps them maintain their nutritional value, texture, and flavor. Freeze drying results in a highquality product because of the low temperature used in processing (Ratti, 2008). Due to the reduced water content of the freeze-dried foods that inhibit the growth of microorganisms, these foods are considered shelfstable and can be kept safe from spoilage for years by preventing the reabsorption of moisture. Freeze-dried foods can be stored in room temperature without refrigeration.
Besides, a balanced diet is one which provides all the nutrients in the required amounts and proper proportions. Supplemented additives, vegetables are added in soup (in powder form) to provide plant proteins, carbohydrate, fiber and minerals. A balanced diet should provide around $10-35 \%$ of total calories from protein, $20-35 \%$ from fat and $45-65 \%$ from carbohydrates (preferably from complex carbohydrates) (Thompson and Manore, 2017). In addition, a balanced diet should provide other non-nutrients such as dietary fibre, antioxidants and phytochemicals which positive health benefits. Antioxidants such as vitamins $\mathrm{C}$ and $\mathrm{E}, \beta$-carotene, riboflavin and selenium protect the human body from free radical damage. Other phytochemicals such as polyphenols, flavones, etc., also afford protection against oxidant damage.

Potato, pumpkin, tomato, carrot as supplementary ingredients due to their nutritional contents which make them a complete nutritional source for a regular diet. These vegetables are also the most important sources of phytochemicals, they can be considered benefits for health are mainly due to high antioxidant activity. So, all these sources complement can make the soup an ideal healthy food for all people. The present research work 
has been aimed to formulate a dehydrated instant soup mix from freeze-dried chicken and vegetables (potato, carrot, tomato, pumpkin), spice and seaweed. Their nutritional and sensorial properties to provide the country people with a regular nutritious diet.

\section{Materials and methods}

\subsection{Preparation of raw materials}

\subsubsection{Preparation of industrial chicken breast}

The industrial chicken breast was washed and diced, then steamed in the microwave (on high power) for 3 minutes. Cooked, diced industrial chicken breast was dehydrated by freeze-drying technique. The freezing temperature and time were $-20^{\circ} \mathrm{C}$ and $24 \mathrm{hrs}$, respectively. Pressure and temperature of sublimation drying are fixed, respectively $0.045 \mathrm{mBar}$ and $50^{\circ} \mathrm{C}$. Drying time changing from $12,24,36$ to $48 \mathrm{hrs}$. Then, the moisture content $(\%)$, protein content (\%), lipid content $(\%)$ and color of the freeze-dried chicken meat were determined. Experiments were performed in triplicate.

\subsubsection{Preparation and processing of raw materials}

Carrot, pumpkin, tomato and potato were sorted, washed, peeled, sliced (carrot in cubes) and followed by dipping in 300 ppm sodium metabisulphite $\left(\mathrm{Na}_{2} \mathrm{~S}_{2} \mathrm{O}_{5}\right)$ solution for 30 mins, then steamed in microwave 5 mins and soaked in cold water. Hot air drying then was performed at constant temperatures $\left(70^{\circ} \mathrm{C}\right)$. The drying models were applied (Ngo Van Tai et al., 2019). The dried materials were ground by using a grinder followed by sieving through $0.5 \mathrm{~mm}$ metallic sieves to yield granulated powder. The prepared granulated powder was packed in polyethylene pouches for further use in the preparation of soup.

\subsubsection{Processing of potato starch}

The potato was purchased from the local market and was peeled, washed, and was ground in the grinder to get a homogenous suspension. The suspension was strained through a cloth and was allowed to stand for few hours for weighing deposition of starch at the bottom. The supernatant was removed and the starch was washed thoroughly and then dried in the oven. Finally, it was ground into a powder with very fine particle (by sieving $0.25 \mathrm{~mm}$ ).

The other ingredients as full cream milk powder (Anchor, New Zealand), milk powder (Dutch Lady, Viet Nam), dried Ottogi seaweed (Korea), seasoning (Knorr, Viet Nam) and table sugar (Bien Hoa, Viet Nam) were purchased from the supermarket in Can Tho city (Viet Nam).

\subsection{Drying procedure}

The reduction of moisture ratio with drying time was used to analyse the experimental drying data. The moisture ratio, $\mathrm{MR}$, was calculated as follows: $\mathrm{MR}=\mathrm{M}$ / $\mathrm{M}_{\mathrm{o}}$ (Doymaz, 2007a), where $\mathrm{M}$ and $\mathrm{M}_{\mathrm{o}}$ are moisture content at any time of drying ( $\mathrm{kg}$ water $/ \mathrm{kg}$ dry matter) and initial moisture content ( $\mathrm{kg}$ water $/ \mathrm{kg}$ dry matter), respectively.

The moisture ratio curves obtained were fitted with Page model (Singh et al., 2008) in order to describe the drying characteristics of plant materials: $\mathrm{MR}=\exp \left(-\mathrm{kt}^{\mathrm{n}}\right)$, where $\mathrm{t}$ is drying time ( $\mathrm{min}$ ) and $\mathrm{k}$ is drying constantly.

\subsection{Formulation of mixed soup}

All the ingredients were mixed into 4 formulations according to the specified ratio for the development of soup mix (Table 1). The total components are $100 \%$. In this case, the moisture content of the product after mixing $(\%)$, water activity $\left(\mathrm{a}_{\mathrm{w}}\right)$ of the product were analysed. The sensory evaluation was done by Quantitative description method (QDA). The total energy (kcal) and the percentage of energy supplied from the selected mixing formula were calculated and the percentage daily value (\% DV) was defined.

Cooking procedures of soup powders: $30 \mathrm{~g}$ of mixed soup was added into $300 \mathrm{~mL}$ water and boiled for $2_{-}$ 3 mins and readied for serving one person.

Table 1. Formulation of mixed soup

\begin{tabular}{lcccc}
\hline \multirow{2}{*}{ Content of Ingredients (g) } & \multicolumn{4}{c}{ Formulas } \\
\cline { 2 - 5 } & I & II & III & IV \\
\hline Freeze-dried chicken & 7.7 & 8.2 & 8.7 & 9.2 \\
Potato starch & 30.3 & 29.8 & 29.3 & 28.8 \\
Full cream milk powder & 22.2 & 22.7 & 23.2 & 23.7 \\
Pumpkin powder & 3.4 & 2.9 & 2.4 & 1.9 \\
Tomato powder & 3.2 & 3.2 & 3.2 & 3.2 \\
Carrot (flake) & 3.8 & 3.8 & 3.8 & 3.8 \\
Potato powder & 3.8 & 3.8 & 3.8 & 3.8 \\
Milk powder & 9 & 9 & 9 & 9 \\
Seaweed & 2.4 & 2.4 & 2.4 & 2.4 \\
Seasoning & 11.4 & 11.4 & 11.4 & 11.4 \\
Table sugar & 2.8 & 2.8 & 2.8 & 2.8 \\
\hline Total & 100 & 100 & 100 & 100 \\
\hline
\end{tabular}

\subsection{Nutrients analysis}

The chemical composition of meat and vegetables such as basic nutrients protein, moisture and fat determined by using standard methods (AOAC, 2000). The total carbohydrate content was determined according to the method of McCseady (1970) and Dubois et al. (1956). The determination of calcium, sodium and potassium was carried out by flame photometry, 
following the procedure of Arunkumar et al. (2015), using FP6410 Flame Photometer. The cholesterol content was determined according to the method of Dinh et al. (2008). Vitamin C was determined by Indophenol method (Zvaigzne et al., 2009). A SP-UV1000 Spectrophotometer 200 1000 $\mathrm{nm}$ was used to measure absorbance at $450 \mathrm{~nm}$ in glass cuvettes for total carotenoid analysis (Parrish, 1977).

The water activity $\left(\mathrm{a}_{\mathrm{w}}\right)$ and the color of the soup mixtures were measured using Rotronic Hygro Palm HP23-AW-A-SET-40 (USA) and a hand-held Chromameter (model CR-400, Konica Minolta, Japan), respectively. Aerobic mesophilic plate count was performed in accordance with the ISO 4833-2:2013/Cor. 1:2014 standard.

Total calories of the soup mixtures was calculated by the formula as follows: total calories $(\mathrm{kcal})=$ fat $(\mathrm{g}) \times 9$ $(\mathrm{kcal} / \mathrm{g})+$ protein $(\mathrm{g}) \times 4(\mathrm{kcal} / \mathrm{g})+$ total carbohydrate (g) $x 4(\mathrm{kcal} / \mathrm{g})$ (Thompson and Manore, 2017).

\subsection{Calculation of percentage daily value $(\% D V)$}

The percentage daily value $(\% \mathrm{DV})$ on the Nutrition Facts label is a guide to the nutrients in one serving of food. DVs are based on a 2,000-calorie diet for healthy adults. Even if your diet is higher or lower in calories, you can still use the DV as a guide. For example, it tells you whether a food is high or low in a specific nutrient, defined as follows: low: $5 \%$ or less of a nutrient and high: $20 \%$ or more of a nutrient. The $\% \mathrm{DV}$ for a nutrient is calculated by dividing the amount of a nutrient in a serving size by its daily value, then multiplying that number by 100 (Thompson and Manore, 2017).

\subsection{Statistical analysis}

Data analyses were carried out using STATGRAPHICS Centurion XV (U.S.A.). Values were expressed as percentage and mean $\pm \mathrm{SD}$. The significance/ non-significance of results was determined using oneway ANOVA and Duncan test.

\section{Results and discussion}

\subsection{Chemical properties of industrial chicken breast in Viet Nam}

Data pertaining to the chemical composition of the industrial chicken breast used for soup mix were analysed. It contained $68.2 \pm 0.85 \%$ moisture, $22.15 \pm 0.68 \%$ protein and $5.46 \pm 0.96 \%$ fat. This finding was almost consistent with Kumar and Rani (2014), they reported that the crude protein of breast fillet with skin about $16.78 \pm 0.26$ to $21.31 \pm 0.21 \%$ (from various commercial brands available in the market), the fat percentage of breast fillet with skin was $2.92 \pm 0.11$ to
$10.22 \pm 0.57 \%$ and the moisture $56.8 \pm 0.93-79.87 \pm 0.27 \%$. The chemical composition of poultry meat is strongly influenced by the bird feeding method (Pisulewski, 2005).

\subsection{Moisture and carbohydrate content of potato, carrot, tomato, pumpkin}

Potato (Solanum tuberosum L.) is a starchy crop used as materials to many types of food production. The results of our present study found that the moisture and carbohydrate content of potato tubers was $80.34 \pm 0.59 \%$ and $13.39 \pm 0.18 \%$. Similar data were observed by Leonel et al. (2017), they revealed that the moisture of potato tubers in a range of 78.17 to $88.11 \%$, which is influenced by the combination of soil $\mathrm{P}$ availability and cultivars. Puttongsiri et al. (2012) reported the potato consisting of $63-83 \%$ moisture content, $13-30 \%$ carbohydrate. Minor differences in content from various studies may be due to varieties, production area, cultivars, soil and climate, agricultural practice (Arvanitoyannis et al., 2008).

In recent years, the consumption of carrot and its products in Viet Nam have increased steadily due to their recognition as an important source of natural antioxidants, such as the anticancer activity of $\beta$-carotene (a precursor of vitamin A). The edible portion of carrots contained about $88.47 \pm 0.36 \%$ moisture and $9.67 \pm 0.84 \%$ carbohydrates. These results are quite similar to the study of Gopalan et al. (1991), they have reported the chemical constituents of carrot as moisture $86 \%$ and carbohydrate $10.6 \%$.

Tomatoes are the major dietary source of the antioxidant lycopene, which has been linked to many health benefits, including reduced risk of heart disease and cancer. The moisture and carbohydrate content of tomatoes were analyzed about $93.85 \pm 0.66 \%$ and $3.95 \pm 0.21 \%$, respectively. The simple sugar as glucose and fructose make up almost $70 \%$ of the carbohydrate content. Roe et al. (2013) have published the water and carbohydrate content of tomatoes of $94.6 \%$ and $3 \%$, respectively. In addition, tomatoes contain high levels of water-soluble vitamins, fat-soluble vitamins, monounsaturated and polyunsaturated fatty acids.

The moisture content of pumpkin is about $91.5 \%$, it is similar to the research results of Doymaz (2007b) and Arévalo-Pinedo and Murr (2007) with the moisture content of pumpkin achieved of $92.4 \%$ and $94 \%$, respectively. The carbohydrate content measured in pumpkin as $3.4 \pm 0.16 \%$. Kim et al. (2012) reported the chemical compositions of each pumpkin species, the contents of the flesh of $C$. maxima, C. pepo were $26.23 \pm 0.20 \mathrm{~g}$ carbohydrate $/ \mathrm{kg}$ raw weight and $42.39 \pm 0.84 \mathrm{~g} / \mathrm{kg}$, respectively. There are differences in 
the concentration of these compounds in raw materials. This is probably due to different varieties and growing conditions.

3.3 Effect of drying process on the quality of plant material (potatoes, pumpkins, tomatoes and carrots) involved in soup powder processing

\subsubsection{The moisture ratio}

The suitable drying time of different types of vegetables was obtained at a drying air temperature of $70^{\circ} \mathrm{C}$. In order for the final material to reach a moisture content of $6-8^{\circ} \mathrm{C}$, the drying times of the different materials are selected $(3 \mathrm{hrs} 20 \mathrm{mins}, 3 \mathrm{hrs}, 4 \mathrm{hrs} 30 \mathrm{mins}$ and $4 \mathrm{hrs} 20$ mins for potato, pumpkin, tomatoes and carrot, respectively). The Page model (eq. 1, 2, 3 and 4) could be used to describe the drying characteristics potato, pumpkin, tomato and carrot, respectively, with the highest value of $R^{2}(\geq 0.97)$.

$\begin{array}{lll}\text { For potato: } & \mathrm{MR}=\exp \left(-0.019 \mathrm{t}^{1.0705}\right) & \mathrm{R}^{2}=0.99 \\ \text { For pumpkin: } & \mathrm{MR}=\exp \left(-0.023 \mathrm{t}^{1.05}\right) & \mathrm{R}^{2}=0.99 \\ \text { For tomato: } & \mathrm{MR}=\exp \left(-0.018 \mathrm{t}^{0.975}\right) & \mathrm{R}^{2}=0.99 \\ \text { For carrot: } & \mathrm{MR}=\exp \left(-0.033 \mathrm{t}^{0.972}\right) & \mathrm{R}^{2}=0.97\end{array}$

\subsubsection{Carbohydrate content}

Carbohydrate content was significantly higher for dried vegetables (in powder form) compared to fresh vegetables. After drying at $70^{\circ} \mathrm{C}$ with different times to obtain the required moisture level $(6-8 \%)$, the carbohydrate contents of potato powder, pumpkin powder, tomatoes powder and carrot flake were $82.87 \pm 0.098, \quad 63.92 \pm 0.104, \quad 51.59 \pm 0.144$ and $65.04 \pm 0.11 \%$, respectively. It has been noticed that the fresh vegetables are poor sources of carbohydrate and they could supply little or no energy when consumed.

\subsection{Effect of drying time on the quality of freeze-dried chicken breast}

The moisture content of freeze-dried chicken decreased during the drying process (12 to $48 \mathrm{hrs}$ ) (Table 2). According to Genin et al. (1995), to prolong the preservation time of freeze-dried products, the moisture content of the product must meet the requirement (less

Table 2. Effect of drying time on the content of moisture, protein and lipid of the freeze-dried chicken

\begin{tabular}{cccc}
\hline $\begin{array}{c}\text { Freeze-drying } \\
\text { time (hour) }\end{array}$ & $\begin{array}{c}\text { Moisture } \\
\text { content }(\%)\end{array}$ & $\begin{array}{c}\text { Protein content } \\
(\%)\end{array}$ & $\begin{array}{c}\text { Lipid content } \\
(\%)\end{array}$ \\
\hline 12 & $8.56 \pm 0.46^{\mathrm{d}}$ & $80.94 \pm 1.22^{\mathrm{a}}$ & $8.65 \pm 0.05^{\mathrm{a}}$ \\
24 & $3.25 \pm 0.20^{\mathrm{c}}$ & $83.72 \pm 2.00^{\mathrm{b}}$ & $9.14 \pm 0.06^{\mathrm{b}}$ \\
36 & $2.24 \pm 0.29^{\mathrm{b}}$ & $84.20 \pm 0.88^{\mathrm{c}}$ & $9.43 \pm 0.09^{\mathrm{c}}$ \\
48 & $1.62 \pm 0.26^{\mathrm{a}}$ & $85.49 \pm 0.85^{\mathrm{d}}$ & $9.74 \pm 0.26^{\mathrm{d}}$ \\
\hline
\end{tabular}

Values are expressed as mean \pm SD. Values with different superscripts are significantly different $(\mathrm{P}<0.05)$. than $4.5 \%)$. The time of freeze-dried for chicken was selected at $24 \mathrm{hrs}(3.25 \pm 0.2 \%)$.

The protein content of freeze-dried chicken increased when drying time increased from $12 \mathrm{hrs}$ (protein content was $80.94 \pm 1.22 \%$ ) to $48 \mathrm{hrs}$ (protein content was $85.49 \pm 0.85 \%$ ). Similarly, the lipid content of the product also increased markedly with respect to increased drying time from $12(8.65 \pm 0.05 \%)$ to $48 \mathrm{hrs}$ $(9.74 \pm 0.26 \%)$. During drying, heat and moisture transfers are coupled. It is a simultaneous heat and moisture transfer process where moisture leaves the food in the form of vapour, while oil and protein content are not significantly changed.

The moisture loss, color development and texture are the most important factors for describing the quality of freeze-dried food products. The obtained results showed that the color values $\mathrm{L}^{*}$ and $\mathrm{b}^{*}$ of chicken were not significantly changed during freeze-drying $\left(\mathrm{L}^{*}\right.$ and $\mathrm{b}^{*}$ in the ranges of 57.1-57.9 and 16.5-17.5, respectively). According to Shishehgarha et al. (2002), freeze-dried products keep light yellow color better than conventional dried. Freeze drying is a low-temperature dehydration process which involves freezing the product, lowering pressure, then removing the ice by sublimation, so the brown color is not formed due to vacuum pressure and lower temperatures in drying.

\subsection{Effect of the proportion of ingredients to the healthy diet}

A healthy diet is a diet that helps to maintain or improve overall health. A healthy diet provides the body with essential nutrition: fluid, macronutrients, micronutrients and adequate calories.

\subsubsection{Standardization of soup mix}

The content of energy-yielding nutrients of the ingredients involved in making soup was presented in Table 3. The results showed that an increase in energy from the formula I to IV (Table 4) due to the amount of carbohydrate and lipid increased in the formula.

Table 3 . The content (\%) of carbohydrate, lipid and protein of the ingredients

\begin{tabular}{lccc}
\hline \multicolumn{1}{c}{ Ingredients } & $\begin{array}{c}\text { Carbohydrate } \\
(\%)\end{array}$ & $\begin{array}{c}\text { Lipid } \\
(\%)\end{array}$ & $\begin{array}{c}\text { Protein } \\
(\%)\end{array}$ \\
\hline Freeze-dried chicken & 0 & 8.65 & 80.94 \\
Potato starch & 83.7 & 0 & 0 \\
Full cream milk powder & 0 & 33 & 0 \\
Pumpkin powder & 63.29 & 3.57 & 14.29 \\
Tomato powder & 51.32 & 0.44 & 12.91 \\
Carrot (flake) & 64.96 & 1.49 & 8.1 \\
Potato powder & 82.86 & 0.34 & 6.9 \\
Milk powder & 60 & 12 & 6.5 \\
Seaweed & 42 & 1.5 & 20 \\
Seasoning & 30 & 2 & 15 \\
Table sugar & 96.21 & 0 & 0 \\
\hline
\end{tabular}


Table 4. Total energy provided by carbohydrate, protein and fat in 4 formulas of mixed chicken vegetable soup (in $100 \mathrm{~g}$ )

\begin{tabular}{ccccc}
\hline Formula & $\begin{array}{c}\text { Carbohydrate } \\
(\mathrm{g})\end{array}$ & $\begin{array}{c}\text { Protein } \\
(\mathrm{g})\end{array}$ & $\begin{array}{c}\text { Lipid } \\
(\mathrm{g})\end{array}$ & $\begin{array}{c}\text { Total Energy } \\
(\mathrm{kcal})\end{array}$ \\
\hline I & 35.08 & 11 & 8.94 & 271.6 \\
II & 41.41 & 11 & 9.21 & 299.75 \\
III & 44.51 & 9.22 & 9.58 & 299.3 \\
IV & 46.37 & 9.3 & 11.64 & 315.95 \\
\hline
\end{tabular}

\subsubsection{The moisture content and water activity}

The moisture content and water activity $\left(\mathrm{a}_{\mathrm{w}}\right)$ of the products produced by four formulas showed no significant difference, ranging from $7.036 \pm 0.456$ to $7.506 \pm 0.569 \%$ and $0.208 \pm 0.009$ to $0.210 \pm 0.012 \%$, respectively. The minimum $\mathrm{a}_{\mathrm{w}}$ at which microorganisms can grow is 0.60 . The minimum $a_{w}$ for growth of most bacteria is approximately 0.87 , although halophilic bacteria can grow at $\mathrm{a}_{\mathrm{w}}$ as low as 0.75 (Beuchat et al., 2013). According to the International Commission on Microbiological Specifications for Foods (1996), under optimal conditions, $\mathrm{S}$. aureus can grow at $\mathrm{a}_{\mathrm{w}}$ as low as 0.83 .

\subsubsection{Sensory characteristics}

Besides the requirements of nutritional value, organoleptic value is also an important indicator that directly affects consumers' decision on product selection. In the processing of mixed soup, determining the appropriate mixing ratio of ingredients not only produces balance nutrition but also enhances the sensory value of the product. The sensory values of instant soup were assessed according to the quantitative descriptive analysis method and represented in Figure 1.
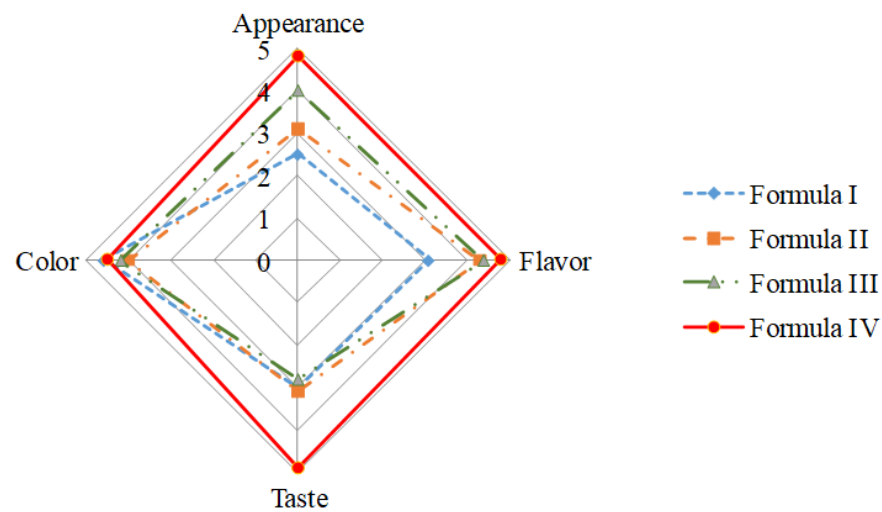

Figure 1. Graphical display of sensory attributes of four samples from four formulas based on QDA results

The viscosity, lumpiness, odor, taste and color of nutritional soup products in each formulation are shown. Nutritional soup has a characteristic flavor. One of the strongest odors in the nutritional soup is the smell of milk powder, which enhances the flavor and creates an attractive flavor for the product. The formula IV combined a sufficient amount of milk powder to create a characteristic flavor that is most preferred by consumers.

The consistency of nutritional soup products decreased from formula I to formula IV. Formula IV was chosen by the majority of consumers. This may be due to a decrease in the amount of potato starch from the formula I to formula IV and the consumers did not like the product too thick/viscous. With the proper concentration of the ingredients which were mixed in formula IV, the results showed that the product has a straw yellow color and the seaweed's green color, bright and attractive. Based on data obtained, along with the sensory evaluation, formula IV has been chosen as a standard sample.

3.5.4 The nutritional values, energy-yielding and energy balance in selected formula (formula IV) of mixed soup

The percentage of energy supplied from major nutrients in formula IV is presented in Table 5. A diet that is balanced in its macronutrient distribution can help reduce the risk of disease and foster lasting weight loss. Acceptable macronutrient distribution ranges (AMDRs) for a particular energy source is associated with reducing the risk of chronic disease while providing intakes of essential nutrients. An intake outside of the AMDR carries the potential of increased risk of chronic diseases and/or insufficient intake of essential nutrients. Acceptable Macronutrient Distribution Ranges for Adults (as a percentage of calories) are as follows: protein: $10-35 \%$, fat: $20-35 \%$, carbohydrate: $45-65 \%$. Food sources that provide carbohydrate, protein \& fat also provide other essential nutrients. A balance of the macronutrients can help ensure adequate intakes of micronutrients as well.

Table 5. Macronutrients content, yielding-energy and percentage of energy providing from $100 \mathrm{~g}$ of mixed chicken vegetable soup

\begin{tabular}{lccc}
\hline Nutrients & $\begin{array}{c}\text { Content } \\
(\mathrm{g})\end{array}$ & $\begin{array}{c}\text { Energy-yielding } \\
\text { nutrients (kcal) }\end{array}$ & $\begin{array}{c}\text { Percentage of } \\
\text { energy providing } \\
\text { from nutrients }\end{array}$ \\
\hline Carbohydrate & 46.37 & 185.48 & 58.744 \\
Lipid & 9.3 & 83.7 & 26.509 \\
Protein & 11.64 & 46.56 & 14.746 \\
\hline Total & & 315.74 & 100 \\
\hline
\end{tabular}

Our obtained results showed that the percentage of Calories from macronutrients in this formula was within the AMDR, with Calories percentages from carbohydrates, proteins and lipids are 58.74, 14.746, $26.509 \%$, respectively. A diet that is balanced in its macronutrient distribution is recommended for lasting weight loss because unbalanced nutrient profiles may increase the risk of adverse health consequences. The Nutrition Facts label was established (Figure 2). 


\begin{tabular}{|c|c|c|}
\hline \multicolumn{3}{|c|}{ Nutrition Facts } \\
\hline \multicolumn{3}{|c|}{$\begin{array}{l}1 \text { serving per container } \\
\text { Serving size } 30 \mathrm{~g}\end{array}$} \\
\hline \multicolumn{3}{|c|}{$\begin{array}{l}\text { Amount per serving } \\
\text { Calories } \\
\text { Calories from fat } 25.11\end{array}$} \\
\hline \multicolumn{3}{|c|}{ \% Daily Value* } \\
\hline $\begin{array}{l}\text { Total fat } \\
\text { Trans fat }\end{array}$ & $\begin{array}{r}2.79 \mathrm{~g} \\
0 \mathrm{~g}\end{array}$ & $4.29 \%$ \\
\hline Cholesterol & $5.52 \mathrm{mg}$ & $1.84 \%$ \\
\hline Sodium & $54.88 \mathrm{mg}$ & $2.29 \%$ \\
\hline $\begin{array}{l}\text { Total } \\
\text { Carbohydrate }\end{array}$ & $13.91 \mathrm{~g}$ & $4.64 \%$ \\
\hline Fiber & $1.27 \mathrm{~g}$ & $5.1 \%$ \\
\hline Protein & $3.49 \mathrm{~g}$ & \\
\hline Vitamin A & $295.74 \mathrm{mcg}$ & $22.57 \%$ \\
\hline Calcium & $24.71 \mathrm{mg}$ & $2.47 \%$ \\
\hline Vitamin C & $606.4 \mathrm{mg}$ & \\
\hline Iron & $0.21 \mathrm{mg}$ & $1.17 \%$ \\
\hline Potassium & $77.95 \mathrm{mg}$ & $2.22 \%$ \\
\hline
\end{tabular}

Figure 2. Nutrition facts of mixed chicken vegetable soup

As General Guide to Calories (based on a 2,000 calorie diet): 40 calories is low, 100 calories is moderate and 400 calories or more is high. The calculated energy of this product is moderate (99.93 calories). The \%DV on the Nutrition Facts label is a guide to the nutrients in one serving of food. The calculated $\% \mathrm{DV}$ showed that $\%$ $\mathrm{DV}$ of vitamin A is $22.57 \%$, it means that the content of this component in the product is high $(20 \%)$. Eating enough of this nutrient can improve your health and help reduce the risk of some diseases and conditions. Some of the components are identified as the limit, such as fat, saturated fat, trans fat, cholesterol, or sodium. The calculated \%DV of cholesterol (1.84\%), fat (4.29\%), sodium $(2.29 \%)$, and carbohydrate $(4.64 \%)$ of this product were less than $5 \%$, indicating good nutrition product. The high amounts of these components may increase the risk of certain chronic diseases, like heart disease, some cancers, or high blood pressure. Health experts recommend that we keep our intake of saturated fat, trans fat and cholesterol as low as possible as part of a nutritionally balanced diet. However, the product also has a relatively low fiber content $(\% \mathrm{DV}$ is $5.1 \%)$, calcium $(2.47 \%)$, potassium $(2.22 \%)$ and iron $(1.17 \%)$. So a diet rich in fruits, vegetables, and grain products that contain dietary fiber, calcium, potassium and iron should be added. The Footnote in the lower part of the nutrition label tells you "\%DVs are based on a 2,000 calorie diet". This statement must be on all food labels. With the energy and nutritional value provided, this product can be used to meet a part of the energy requirement for breakfast or lunch.
Besides, the Glycemic Index (GI) that is proven most helpful to people with diabetes and those who are overweight. If we choose healthy low GI foods, at least one at each meal, chances are you're eating a diet that not only keeps blood glucose 'on an even keel' but also contains balanced amounts of carbohydrates, fats and proteins. Most ingredients have a GI below 55, except for potato starch (GI>70) and refined sugar (a GI of 100) (Atkinson et al., 2008). However, when eating high GI and low GI foods together in a meal, the GI of a meal will have an average value. Eating a variety of foods in a meal (with sugar, protein, fat, vegetables) has the effect of preventing fast sugar absorption, so the GI of meals is also reduced. The healthy chicken vegetable soup could be used well in any meal of the day to support and supplement precious nutrients for humans. This is also a convenient product with quick preparation.

\subsubsection{The quality of stored mixed chicken vegetable soup}

Storage of products is important and necessary. Among the packaging containing the products to be studied, zipper reclosable aluminium bags double-sided was selected. After five months of storage, the moisture content and water activity of the product contained in zipper reclosable aluminium bags double-sided remains unchanged, $7.04 \pm 0.46 \%$ and $0.21 \pm 0.004$, respectively. Besides, the organoleptic value of the product was also well evaluated and the microbiological content of the total analytical value is low $(3.3 \pm 0.1 \mathrm{CFU} / \mathrm{g})$ (Vietnamese Standard - QCVN 11-4:2012/BYT).

\section{Conclusion}

The healthy chicken vegetable soup powder is formulated. The Nutrition Facts label has been published for this product from computational data, providing good support for product selection in accordance with different consumer health conditions. On the physicochemical and microbiological point of view, this soup powder is acceptable up to 5 months. With the full presence of nutrients from different materials and proper energy balance, the soup powder is developed as an appropriate choice for the fulfilment of nutritional demand, especially for the prevention of the proteinenergy malnutrition in our country.

\section{References}

AOAC. (2000). Official methods of analysis of AOAC International. $17^{\text {th }}$ ed. Gaithersburg, MD, USA: AOAC.

Arévalo-Pinedo, A. and Murr, F.E.X. (2007). Influence of pre-treatments on the drying kinetics during vacuum drying of carrot and pumpkin. Journal of 
Food Engineering, 80(1), 152-156. https:// doi.org/10.1016/j.jfoodeng.2006.05.005

Arunkumar, D., Avinash, N.G., Rao, H., Robin, K.B. and Samshuddin, S. (2015). Estimation of calcium, potassium and sodium contents in commonly consumed food of Karnataka coastal belt region, India. Pelagia Research Library. Der Chemica Sinica, 6(4), 100-103

Arvanitoyannis, I., Vaitsi, O. and Mavromatis, A. (2008). Potatoes: a comparative study of the effect of cultivars and cultivation conditions and genetic modification on the physico-chemical properties of potato tubers in conjunction with multivariate analysis towards authenticity. Critical Reviews in Food Science and Nutrition, 48(9), 799-823. https:// doi.org/10.1080/10408390701691059

Atkinson, F.S., Foster-Powell, K. and Brand-Miller, J.C. (2008). International tables of glycemic index and glycemicload values. Diabetes Care, 31(12), 22812283. https://doi.org/10.2337/dc08-1239

Beuchat, L.R., Komitopoulou, E., Beckers, H., Betts, R.P., Bourdichon, F., Fanning, S., Joosten, H.M. and Kuile, B.H.T. (2013). Low-Water Activity Foods: Increased Concern as Vehicles of foodborne Pathogens. Journal of Food Protection, 76(1), 150172. https://doi.org/10.4315/0362-028X.JFP-12-211

Dinh, T.T.N., Blanton, J.R., Brooks, Jr. J.C., Miller, M.F. and Thompson, L.D. (2008). A simplified method for cholesterol determination in meat and meat products. Journal of Food Composition and Analysis, 21(4), 306-314. https://doi.org/10.1016/ j.jfca.2008.02.001

Doymaz, I. (2007a). The kinetics of forced convective air-drying of pumpkin slices. Journal of Food Engineering, 79(1), 243-248. https:// doi.org/10.1016/j.jfoodeng.2006.01.049

Doymaz, I. (2007b). Influence of pretreatment solution on the drying of sour cherry. Journal of Food Engineering, 78(2), 591-596. https:// doi.org/10.1016/j.jfoodeng.2005.10.037

Dubois, M., Gilles, K.A., Hamilton, J.K., Rebers, P.A. and Smith, F. (1956). Colorimetric method for the determination of sugars and related substances. Analytical Chemistry, 28, 350 - 356. https:// doi.org/10.1021/ac60111a017

Genin, N., Rene, F. and Corrieu, G. (1995). A method for on-line determination of residual water content and sublimation end-point during freeze-drying. Journal of Food Engineering, 255-263. https:// doi.org/10.1016/0255-2701(95)04131-1

Gopalan, C., Ramasastry, B.V. and Balasubramanian, S.C. (1991). Nutritive value of Indian foods., p.
47. Hyderabad: National Institute of Nutrition.

International Commission on Microbiological Specifications for Foods. (1996). Microorganisms in foods 5. Microbiological specifications of food pathogens. London: Blackie Academic \& Professional.

ISO (International Standard Organization). Microbiology of food chain - Horizontal method for the enumeration of microorganisms - Part 2 - Colony count at $30^{\circ} \mathrm{C}$ by the surface plating technique. ISO 4833 2:2013/Cor. 1:2014. Geneva, Switzerland: ISO.

Kim, M.Y, Kim, E.J., Kim, Y., Choi, C. and Lee, B. (2012). Comparison of the chemical compositions and nutritive values of various pumpkin (Cucurbitaceae) species and parts. Nutrition Research and Practice, 6(1), 21-27. https:// doi.org/10.4162/nrp.2012.6.1.21

Kumar, R.P. and Rani, M.S. (2014). Chemical composition of chicken of various commercial brands available in market. IOSR Journal of Agriculture and Veterinary Science, 7(7), 22-26. https://doi.org/10.9790/2380-07732226

Leonel, M., do Carmo, E.L., Fernades, A.M., Soratto R.P., Juliana Aparecida Marques Ebúrneo, J.A.M., Garcia, E.L. and do Santos, T.P.R. (2017). Chemical composition of potato tubers: the effect of cultivars and growth conditions. Journal of Food Science and Technology, 54(8), 2372-2378. https:// doi.org/10.1007/s13197-017-2677-6

McCseady, R.M. (1970). Determination of starch and dextrin in methods of Food Analysis, 2nd edition. A series of monographs, D.225-227. London, UK: Academic Press.

Ngo Van Tai, Nguyen Minh Thuy, Tran Linh Triep, Le Thuy Hang and Nguyen Thi Truc Ly. (2019). Formulation of instant soup powder from freezedried shrimp and locally available vegetables. Journal of Vietnam Agricultural Science and Technology, 6, 100-104.

Parrish, D.B. (1977). Determination of vitamin A in foods-a review. CRC Critical Reviews in Food Science and Nutrition, 9(4), 375-394. https:// doi.org/10.1080/10408397709527240

Pisulewski, P.M. (2005). Nutritional potential for improving meat quality in poultry. Animal Science Papers and Reports, 23(4), 303-315.

Puttongsiri, T., Choosakul, N. and Sakulwilaingam, D. (2012). Moisture content and physical properties of instant mashed potato. International Conference on Nutrition and Food Sciences IPCBEE Vol. 39. Singapore: IACSIT Press.

Ratti, C. (2008). Advances in Food Dehydration. p. 209- 
235. USA: CRC Press. https:// doi.org/10.1201/9781420052534

Roe, M., Church, S., Pinchen, H. and Finglas, P. (2013). Nutrient analysis of fruit and vegetables: Analytical report. Retrieved from website: http:// www.dh.gov.uk/publications, UK.

Shishehgarha, F., Makhlouf, J. and Ratti, C. (2002). Freeze-drying characteristics of strawberries. Drying Technology, 20(1), 131-145. https://doi.org/10.1081/ DRT-120001370

Singh, S.G., Sharma, R., Bawa, A.S. and Saxena, D.C. (2008). Drying and rehydration characteristics of water chestnut (Trapanatans) as a function of drying air temperature. Journal of Food Engineering, 87(2), 213-221. https://doi.org/10.1016/ j.jfoodeng.2007.11.027

Sunyoto, M., Futiawati, R. and Rahimah, S. (2012). The influence of full cream milk powder concentration to the characteristics of "Rasi" instant cream soup. Journal of Agricultural Science and Technology, A2, 1218- 1231.

Thompson, J. and Manore, M. (2017). Nutrition: An applied approach. $5^{\text {th }}$ ed. New York: Pearson.

Zvaigzne, G., Karklina, D., Seglina, D. and Krasnova, I. (2009). Antioxidants in various citrus fruit juices. Chemine Technologija, 3(52), 56-61. 